\title{
ORIENTATION TO MONEY OF AMBITIOUS PERSON
}

\author{
Oksana V. Barsukova ${ }^{1}$, Arina V. Barsukova ${ }^{2}$ \\ ${ }^{1}$ Chair of Psychology of Education, Faculty of Pedagogy and Practical Psychology, \\ Southern Federal University, Russian Federation \\ ${ }^{2}$ Economic faculty, South Federal University, Russian Federation \\ knesinka@mail.ru, arina_barsukova@mail.ru
}

\section{Original Scientific Paper 10.5937/jouproman9-29873}

\begin{abstract}
The article presents the results of an empirical study of orientation to money of ambitious person. Ambition and orientation to money are the motives of a person's social activity. Ambition is a person's desire to become a significant and recognized person for other people. Orientation to money is a person's a person's desire to increase well-being desire to increase well-being. People who consider themselves ambitious have a low (75.75\%) and an average $(24.24 \%)$ orientation to money. People who do not consider themselves ambitious have a low $(85.71 \%)$, average $(7.14 \%)$ and high $(7.14 \%)$ orientation to money.
\end{abstract}

Key words: social activity, ambition, orientation to money, young people (early adolescence)

\section{Introduction}

The social activity of a modern person is the result of a large number of various motives. The processes of social and economic stratification taking place in modern society causes an increased interest in such motives, in particular, ambition and orientationto money [3; 4]. Ambition is a person's striving to become a significant and recognized person to other people for real achievements. These achievements matter to that person himself and to other people [2].
The analysis of psychological sources showed that there are three options for the attitude of an ambitious person to money:

- Money is not a significant goal of an ambitious person. $\mathrm{He} / \mathrm{she}$ is rational about money.

- Money is a significant value for an ambitious person. He/she strives for high material well-being, for the status of a rich, wealthy person.

- An ambitious person demonstrates a disdain for money.

Orientation to money is a person's desire to increase their well-being. Money is the object of psychological evaluation. Obviously, different people have different attitudes towards money. For some, money is the goal and meaning of life, and they are ready to do anything for the sake of money. Someone looks at money as a tool, and someone is indifferent to money, some people view money as evil. Money can be seen as a means to achieve other goals or as a goal in itself. A person's attitude to money develops and forms in the process of education; it depends on the social environment in which a person lives. 
The aim of empirical research is to study the orientation to money of young people who consider themselves ambitious and compare the orientation to money of ambitious and unambitious people. The study of the orientation to money of ambitious young people is a part of a comprehensive study of the motivation of the social activity of the personality [1].

\section{research:}

Methods and object of empirical

Two tests were used at the empirical research: a questionnaire of self-esteem for ambition (O. Barsukova) and a test for the diagnosis of socio-psychological personality attitudes in the motivational-need sphere (O. Potemkina).

The object of empirical research are 94 young people (between the ages of 18 and 25) who are the students of the Southern Federal University (Rostov-onDon, Russia.).

\section{Results of empirical research:}

The study of self-esteem of ambition showed that:

- Majority of thes tudents consider themselves ambitious (70.21\%).

- Less than a third of students do not consider themselves ambitious people (29.79\%).

The study of the orientation to money of ambitious people showed:

- Low orientation to money prevails (75.75\% of young people)

- A quarter of young people have an average orientation towards money (24.24\% of young people).

- Low orientation to money was not revealed.
- The results show that the majority of ambitious young people have a low orientation to money.

The study of the orientation to money of unambitious people showed:

- Low orientation to money prevails ( $85.71 \%$ of young people).

- A very small portion of the students have an average orientation to money $(7.14 \%)$.

- A very small portion of the students have a high orientation to money (7.14\%).

These results point that the majority of unambitious young people have a low orientation to money.

A comparative analysis of the money' orientation of ambitious and unambiguous people showed the following:

- A low orientation towards money slightly prevails among young people who do not consider themselves ambitious (85.71\%) compared with young people who consider themselves ambitious $(75.75 \%)$. But these differences are not significant ( $U=202,500$, $\mathrm{p}=0.05$ ).

- An average orientation towards money is predominant among young people who consider themselves ambitious (24.24\%) compared with young people who do not consider themselves ambitious (7.14\%). But these differences are not significant ( $U=312,500, p=0.05)$.

- A high orientation towards money was revealed only among young people who do not consider themselves ambitious. 
(JPMNT) Journal of Process Management - New Technologies, International Vol. 9, No 1, 2021.

\section{Discussion}

We supposed that young people who consider themselves ambitious will have average and / or high orientation to money. Our results were opposite - they have a low orientation to money. However, the results do not contradict information in psychological sources.

We also assumed that there would be a difference in the money orientation of ambitious and unambitious young people. However, we found only one difference - only unambitious people have a high orientation to money.

\section{References:}

1. Barsukova O. [2020]. Orientation to freedom and power of ambitious person in early adolescence // Journal of Process Management - New Technologies, International Vol. 8, No1, P. 47-49.

2. Barsukova O. [2016]. Psychological characteristics of ambitious person // Journal of Process Management - New Technologies, International Vol. 4, No. 2, P. 79-80.

3. Barsukova O., Mozgovaya N., Kosikova L. [2019]. Ambition and personal space as a phenomena of social interaction // Culture and Education: Social Transformations and Multicultural Communication: Proceedings of the Middle-Term Conference RC04 Sociology of Education International Sociological Association (ISA), Institute of Foreign Languages RUDN University, Moscow, 24-26 July 2019. - Moscow: RUDN, 2019. - 673 p.: ill. P. 306-312.

4. Ilyin E.P. [2014]. Psychology of envy, hostility, vanity. - SPb.: Peter. - 208 p.

5. Potemkina O.F. [2001]. Methodology for the diagnosis of socio-psychological attitudes of the individual in the motivational-need-sphere / Practical psychodiagnostics. Techniques and tests. Tutorial. Ed and comp. Raigorodsky D. Samara, S. 641-648 